\title{
Evaluation of Free Radical Scavenging Activity of Ethanolic Extract from Promising Accessions of Curcuma aeruginosa RoxB.
}

\author{
Waras Nurcholis $^{1,2^{*}}$, Nurul Khumaida ${ }^{3}$, Muhamad Syukur ${ }^{3}$, Maria Bintang ${ }^{1}$ \\ ${ }^{1}$ Department of Biochemistry, Bogor Agricultural University, Bogor, Indonesia \\ ${ }^{2}$ Tropical Biopharmaca Research Center (Trop-BRC), Bogor Agricultural University, Bogor, Indonesia \\ ${ }^{3}$ Department of Agronomy and Horticulture, Bogor Agricultural University, Bogor, Indonesia \\ *email: wnurcholis@apps.ipb.ac.id
}

Received May 09, 2017; Accepted July 07, 2017; Available online November 30, 2017

\begin{abstract}
This study evaluated the antioxidant activity through the determination of free radical scavenging activity of ethanolic extracts from 20 accessions of Curcuma aeruginosa, and it is to use for the development of varieties in future. The radical scavenging activity of the extract accessions was investigated with 2,2diphenyl-1-picrylhydrazyl (DPPH) radical. $\mathrm{IC}_{50}$ values for $\mathrm{DPPH}$ radical scavenging activity ranged from 89.81 to $505.65 \mu \mathrm{g} \mathrm{mL}^{-1}$. Based on $\mathrm{IC}_{50}$ values, twenty accessions of $C$. aeruginosa can be divided into three groups: strong (two accessions); moderate (seventeen accessions); and low (one accession) of DPPH scavenger. Sukoharjo (SH) and Muara Bungo (MB) showed promising accessions for antioxidant potential, thus these accessions important to selection for the future breeding program in pharmaceutical products.
\end{abstract}

Keywords: Antioxidant; breeding; DPPH; free radical; temu ireng;

\section{INTRODUCTION}

A free radical is defined as an atom or molecule containing one or more unpaired electron (Bayr, 2005) such as superoxide $\left(\mathrm{O}_{2}^{-}\right)$, hydroxyl $\left(\mathrm{OH}^{-}\right)$, peroxyl $\left(\mathrm{RO}_{2}^{-}\right)$and hydroperoxyl $\left(\mathrm{HO}_{2}^{-}\right)$(Halliwell \& Gutteridge, 2015). Free radicals are the products from biochemical of normal cellular metabolism (Phaniendra, Jestadi, \& Periyasamy, 2015). In vivo, the free radicals have a very reactive with lipid, protein, and DNA (Bhattacharya, 2015) to create a stable compound. Thus, excess of free radicals can seriously damage essential macromolecules of the cell and theirs implicated in many major diseases include cancer (Hecht et al., 2016), cardiovascular diseases (Tostes, Carneiro, Carvalho, \& Reckelhoff, 2016), inflammatory diseases (Rimessi, Previati, Nigro, Wieckowski, \& Pinton, 2016), heart diseases (Sverdlov et al., 2016), respiratory diseases (Guo et al., 2017), diabetes (Onoue et al., 2016), neurological diseases (Radak et al., 2016), aging process (Park, Sim, Lee, Sung, \& Oh, 2016), etc. However, the human body has various mechanisms to counteract free radical by producing antioxidant: (a) enzymatic antioxidant i.e. superoxide dismutase, catalase, and glutathione peroxidase (Park et al., 2016); and (b) non-enzymatic antioxidants i.e. glutathione and nicotinamide adenosine dinucleotide phosphate (Kilanczyk, Saraswat
Ohri, Whittemore, \& Hetman, 2016). But, when the free radical production rate exceeds the capacity there will be a failure of the antioxidant defense system. Therefore, antioxidants need to be supplemented from outside sources.

During the last years, there has been interesting in scientific studies concerning discovery metabolite from the medicinal plant that can be applied to antioxidant (Jeong, Tulasi, \& Koyyalamudi, 2016; Perera, Samarasekera, Handunnetti, \& Weerasena, 2016). Curcuma aeruginosa RoxB. is a medicinal plant that contains phytochemical phenolic, flavonoid (Waras Nurcholis, Khumaida, Syukur, \& Bintang, 2016b) and curcuminoids (Bos et al., 2007; Waras Nurcholis, Khumaida, Syukur, \& Bintang, 2016a), so it's a potential source of natural antioxidant (Amalraj, Pius, Gopi, \& Gopi, 2017; W Nurcholis, Khumaida, Syukur, Bintang, \& Ardyani, 2015). C. aeruginosa has a broad geographical scope in Indonesia, which necessitates extensive investigation on the antioxidant attributes of their different accessions. Therefore, this study, we investigated the free radical scavenging activity of ethanol extract of $20^{\circ} \mathrm{C}$. aeruginosa promising accessions.

\section{EXPERIMENTAL SECTION}

C. aeruginosa rhizomes were collected in the month of February 2015 from different regions 
of Indonesia (Table 1). Most of the accessions were pooled and taken for identified by experts at Tropical Biopharmaca Research Center, Bogor Agricultural University (IPB).

\section{Preparation of ethanolic extract}

The rhizome materials were sun dried to moisture content $<10 \%$ and then powdered (100 mesh). The resulting powder was subjected to extraction with $70 \%$ ethanol (W Nurcholis et al., 2015). The ethanolic extract was concentrated, using a rotary evaporator (BUCHI, R-250, Switzerland) and stored at $4{ }^{\circ} \mathrm{C}$ until used.

\section{Determination of free radical scavenging activity}

The stable 2,2-diphenyl-1-picrylhy drazyl (DPPH) analysis was used to determine free radical scavenging activity of the ethanolic extracts $\left(25,50,100,200,400\right.$ and $800 \mu \mathrm{g} \mathrm{mL}^{-}$ $\left.{ }^{1}\right)$ (W. J. Li et al., 2012). Ethanolic extract (200 $\mu \mathrm{L}$ ) in DMSO (Merck, Germany) was added to $50 \mu \mathrm{L}$ of a methanol solution of DPPH. Absorbance at $517 \mathrm{~nm}$ was determined using microplate readers or microplate photometers
(Epoch Biotech, USA) after incubation in dark for $30 \mathrm{~min}$ at $37{ }^{\circ} \mathrm{C}$, and the percentage inhibition activity was calculated from $\left[\frac{A_{0}-A}{A_{0}}\right] x 100$, where $\mathrm{A}_{0}$ is the absorbance of the control, and $\mathrm{A}$ is the absorbance of the ethanolic extract. The inhibition curves were prepared and, $\mathrm{IC}_{50}$ values were obtained.

\section{Statistical analysis}

The data were analyzed using one-way variance analysis. The comparisons among the difference of means were further analyzed using Duncan's multiple range test at $p<0.05$. Analyses were performed using SPSS 19 statistical computer software.

\section{RESULTS AND DISCUSSION}

Analysis of the free radical scavenging activity of the ethanolic extract from 20 C. aeruginosa accessions tested by a stable free radical, namely DPPH as a reagent. The DPPH method is a preferred method because it is a convenient and fast technique to evaluate free radical scavenging or antioxidant activity (J. Li et al., 2013).

Table 1. Geographical collection sites of 20 C. aeruginosa accessions

\begin{tabular}{|c|c|c|c|c|}
\hline Region accessions & Province & Latitude (S) & Longitude (E) & Altitude (m) \\
\hline Madura (MD) & East Java & $7^{\circ} 02^{\prime} 48.90^{\prime \prime}$ & $112^{\circ} 43^{\prime} 47.32^{\prime \prime}$ & 4 \\
\hline Kediri (KD) & East Java & $7^{\circ} 50^{\prime} 39.52^{\prime \prime}$ & $111^{\circ} 53^{\prime} 54.93^{\prime \prime}$ & 489 \\
\hline Ponorogo (PR) & East Java & $7^{\circ} 51^{\prime} 51.47^{\prime \prime}$ & $111^{\circ} 28^{\prime} 11.78^{\prime \prime}$ & 106 \\
\hline Pacitan (PT) & East Java & $8^{\circ} 11^{\prime} 59.56^{\prime \prime}$ & $111^{\circ} 06^{\prime} 13.34^{\prime \prime}$ & 7 \\
\hline Ngawi (NW) & East Java & $7^{\circ} 29^{\prime} 52.21 "$ & $111^{\circ} 09^{\prime} 22.78^{\prime \prime}$ & 345 \\
\hline Karanganyar (KA) & Central Java & $7^{\circ} 39^{\prime} 49.37^{\prime \prime}$ & $111^{\circ} 08^{\prime} 01.93^{\prime \prime}$ & 1113 \\
\hline Sragen (SG) & Central Java & $7^{\circ} 24^{\prime} 22.14^{\prime \prime}$ & $111^{\circ} 07^{\prime} 12.84^{\prime \prime}$ & 90 \\
\hline Solo (GD) & Central Java & $7^{\circ} 34^{\prime} 08.83^{\prime \prime}$ & $110^{\circ} 49^{\prime} 54.53^{\prime \prime}$ & 95 \\
\hline Solo (KL) & Central Java & $7^{\circ} 35^{\prime} 05.66^{\prime \prime}$ & $110^{\circ} 49^{\prime} 45.38^{\prime \prime}$ & 96 \\
\hline Sukoharjo (SH) & Central Java & $7^{\circ} 44^{\prime} 41.62^{\prime \prime}$ & $110^{\circ} 52^{\prime} 41.14^{\prime \prime}$ & 111 \\
\hline Wonogiri (WG) & Central Java & $7^{\circ} 57^{\prime} 22.83^{\prime \prime}$ & $110^{\circ} 59^{\prime} 37.51^{\prime \prime}$ & 378 \\
\hline Purworejo (PW) & Central Java & $7^{\circ} 44^{\prime} 25.35^{\prime \prime}$ & $110^{\circ} 01^{\prime} 59.00^{\prime \prime}$ & 56 \\
\hline Kendal $(\mathrm{KN})$ & Central Java & $7^{\circ} 00^{\prime} 55.14^{\prime \prime}$ & $110^{\circ} 16^{\prime} 05.98^{\prime \prime}$ & 78 \\
\hline Pakem (PK) & Yogyakarta & $7^{\circ} 39^{\prime} 55.46^{\prime \prime}$ & $110^{\circ} 25^{\prime} 11.30^{\prime \prime}$ & 424 \\
\hline Beringharjo (BH) & Yogyakarta & $7^{\circ} 47^{\prime} 56.40^{\prime \prime}$ & $110^{\circ} 22^{\prime} 01.56^{\prime \prime}$ & 115 \\
\hline Kulonprogo (KP) & Yogyakarta & $7^{\circ} 56^{\prime} 25.03^{\prime \prime}$ & $110^{\circ} 14^{\prime} 20.30^{\prime \prime}$ & 20 \\
\hline Gunung Kidul (GK) & Yogyakarta & $7^{\circ} 58^{\prime} 04.87^{\prime \prime}$ & $110^{\circ} 36^{\prime} 09.67^{\prime \prime}$ & 180 \\
\hline Cirebon (LC) & West Java & $6^{\circ} 48^{\prime} 17.09^{\prime \prime}$ & $108^{\circ} 48^{\prime} 06.04^{\prime \prime}$ & 1 \\
\hline Bogor $(\mathrm{CB})$ & West Java & $6^{\circ} 32^{\prime} 35.89^{\prime \prime}$ & $106^{\circ} 41^{\prime} 22.41^{\prime \prime}$ & 148 \\
\hline Muara Bungo (MB) & Jambi & $1^{\circ} 37^{\prime} 00.61 "$ & $102^{\circ} 22^{\prime} 16.28^{\prime \prime}$ & 65 \\
\hline
\end{tabular}


The DPPH radical is a deep purplish color, which is at its maximum wavelength at 515-520 $\mathrm{nm}$ and can change color from violet to yellow if received an electron or hydrogen from antioxidant molecules to become a stable DPPH molecule (Carmona-Jiménez, GarcíaMoreno, Igartuburu, \& Barroso, 2014; Pérez \& Aguilar, 2013). Therefore, the discoloration of the DPPH radical reflects the free radical scavenging activity of the analyzed extract in 20 C. aeruginosa accessions (Figure 1). The percentage inhibitions of DPPH assay from the ethanolic extract of twenty $C$. aeruginosa promoting accession are given in Figure 2, and the $\mathrm{IC}_{50}$ values are presented in Figure 3. The DPPH radical scavenging capacity was evaluated regarding percent reduction of the initial DPPH absorption. The percentages of inhibition of the Sukoharjo (SH) and Muara Bungo (MB) accessions demonstrated superior DPPH radicals scavenging activity than the others accessions at $25-800 \mu \mathrm{g} \mathrm{mL}^{-1}$.

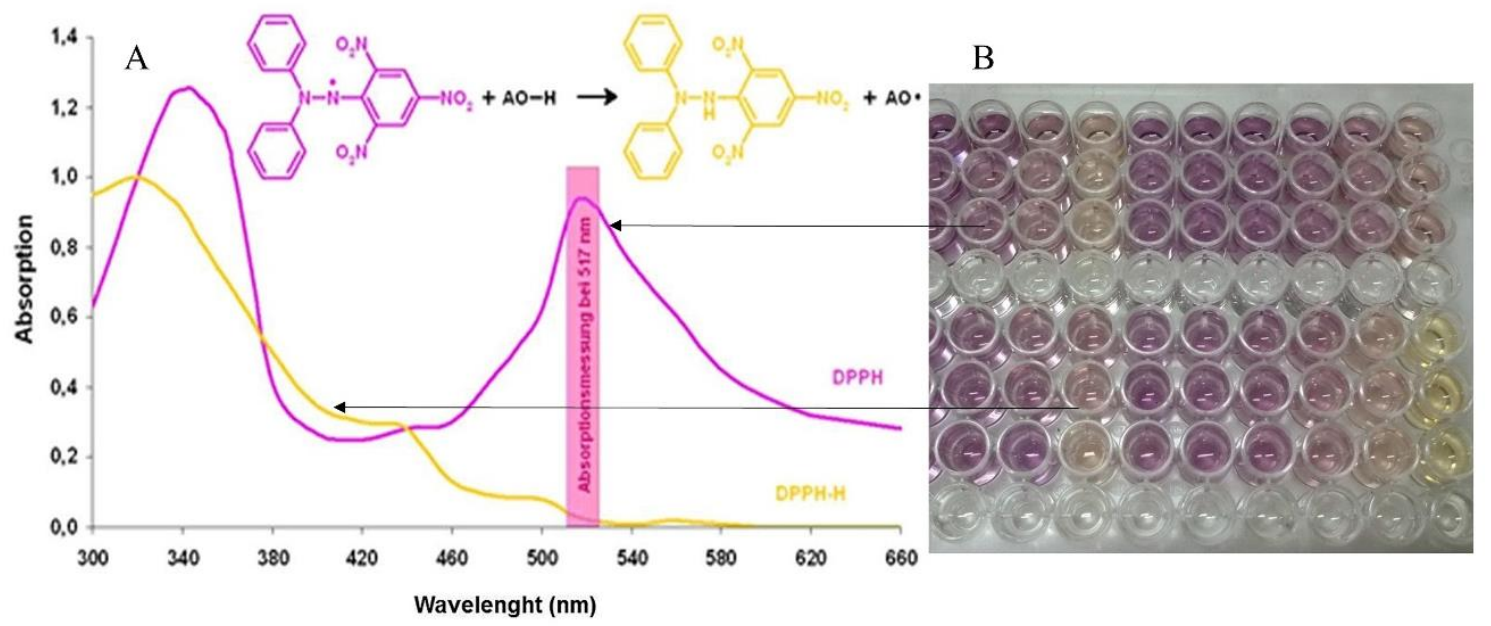

Figure 1. The color change of DPPH: (A) from purple to yellow in graph (Pérez \& Aguilar, 2013) and sample of $C$. aeruginosa in 96-micro plate well (B), when it exposed to antioxidant substance
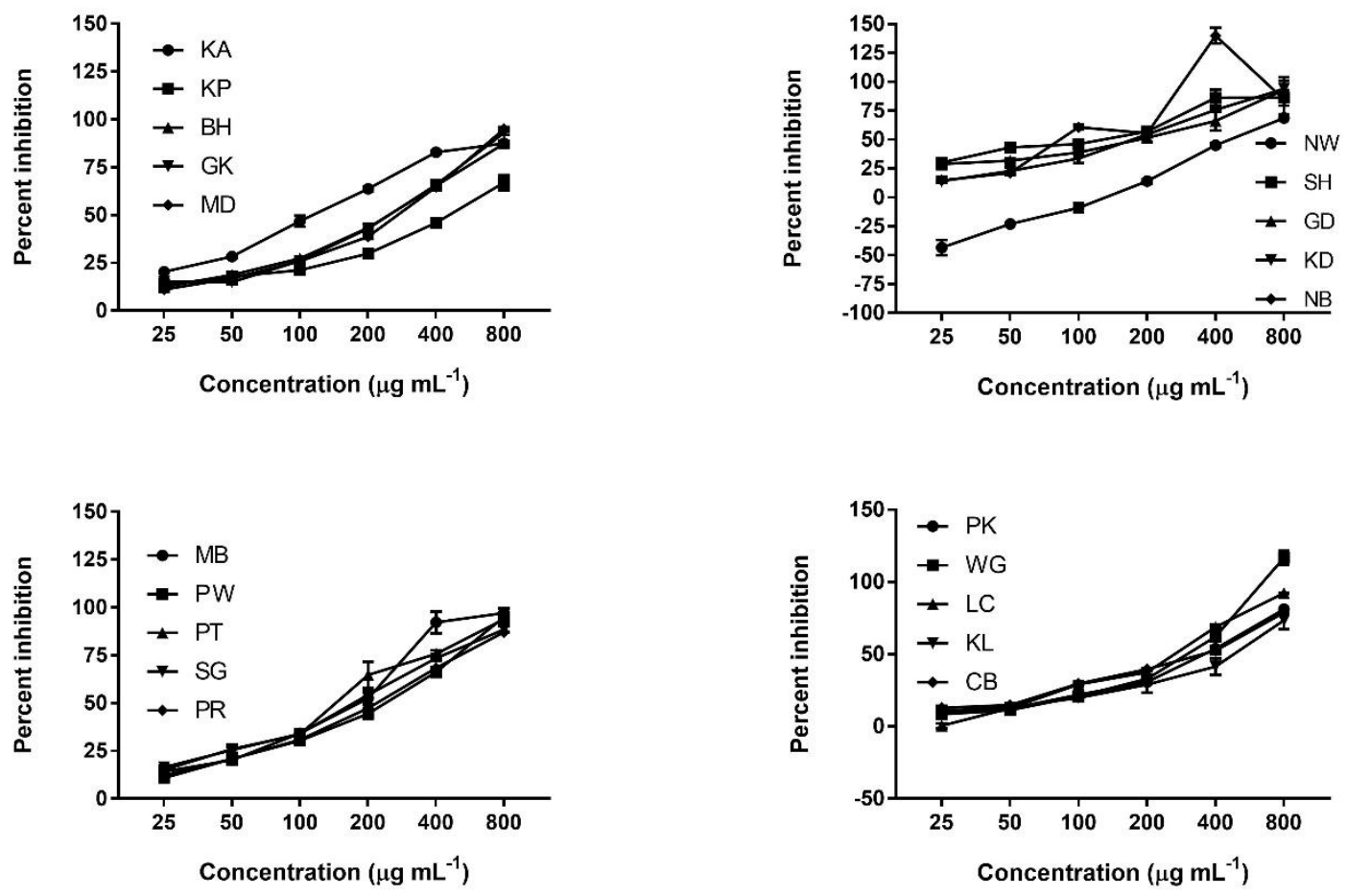

Figure 2. Inhibition activity of twenty $C$. aeruginosa promising accessions ethanolic extracted from DPPH radicals 


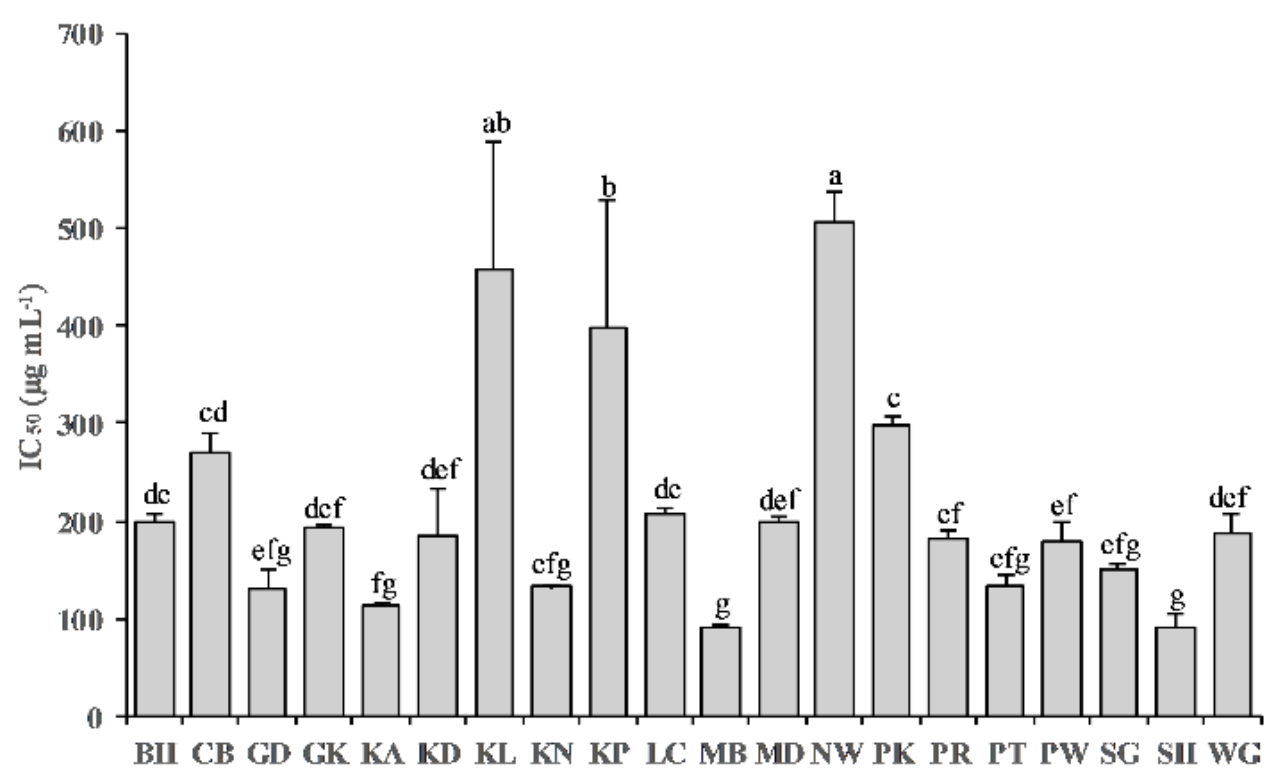

Figure 3. Free radical-scavenging activity in an ethanolic extract of twenty $C$. aeruginosa promising accessions by DPPH assay. Each data represents the mean \pm SD of three replicates. Values with different lowercase letters represent significant differences at $p<0.05$.

The free radical scavenging reported as $\mathrm{IC}_{50}$ values that defined as the concentration of sample extract necessary to obtain an activity of $50 \%$ of the DPPH radicals (Nickavar, Alinaghi, \& Kamalinejad, 2008). The lower $\mathrm{IC}_{50}$ value indicates higher free radical scavenging activity. The $\mathrm{IC}_{50}$ values in the ethanolic extract of $C$. aeruginosa accession ranged from 89.91 to $505.65 \mu \mathrm{g} \mathrm{mL} \mathrm{m}^{-1}$. Accessions of Sukoharjo (SH) and Muara Bungo (MB) had a significantly higher free radical scavenging $(p<0.05)$ compared to others accessions except with accessions of Solo (GD), Kendal (KN), Pacitan (PT) and Sragen (SG). According to $\mathrm{IC}_{50}$ values, the free radical scavenging activity can be divided into three groups: (a) strong with $\mathrm{IC}_{50}<100 \mu \mathrm{g} \mathrm{mL}^{-}$ ${ }^{1}$; (b) intermediate with $\mathrm{IC}_{50}, 100-500 \mu \mathrm{g} \mathrm{mL}^{-1}$; and (c) weak with $\mathrm{IC}_{50}>500 \mu \mathrm{g} \mathrm{mL}^{-1}$ (Bi et al., 2016). Therefore, 20 accessions of $C$. aeruginosa can be divided three groups based on $\mathrm{IC}_{50}$ values. The first group, which is comprised accessions of Sukoharjo (SH) and Muara Bungo (MB), was defined by strong of the radical scavenging activity. The second group consisted of seventeen accessions, including Ponorogo (PR), Pacitan (PT), Karanganyar (KA), Sragen (SG), Solo (GD), Solo (KL), Wonogiri (WG), Purworejo (PW), Kendal (KN), Pakem (PK), Beringharjo (BH), Kulonprogo (KP), Gunung Kidul (GK), Cirebon (LC), Bogor (CB), Madura (MD), and Kediri (KD): this group has relatively intermediate of the free radical scavenging activity. The third group included one accessions of Ngawi (NW) which exhibited relatively low of the radical scavenging activity.

In literature, there are some reports regarding free radical scavenging of $C$. aeruginosa tested by the DPPH method. Based on our result, free radical scavenging capacity in ethanolic extract of twenty $C$. aeruginosa accessions are lower than essential oil extract with $\mathrm{IC}_{50}$ values of $28 \mu \mathrm{g} \mathrm{mL} \mathrm{m}^{-1}$ (George \& Britto, 2015) and $2428 \mu \mathrm{g} \mathrm{mL}^{-1}$ (Theanphong, Mingvanish, \& Kirdmanee, 2013). In another report, the free radical scavenging of the ethanol and oleoresins extracts were $437.07 \mu \mathrm{g}$ $\mathrm{mL}^{-1}$ (W Nurcholis et al., 2015) and $450 \mu \mathrm{g}$ $\mathrm{mL}^{-1}$ (Rajamma, Bai, \& Nambisan, 2012), respectively. The ethanolic extract accessions of Sukoharjo (SH) and Muara Bungo (MB) were shown strong the free radical scavenging activity with $\mathrm{IC}_{50}$ values of 89.81 and 90.87 , respectively. Accessions of $\mathrm{SH}$ and $\mathrm{MB}$ had strong to potent antioxidant activity. This result provides important information for selecting high-quality $C$. aeruginosa rhizome in the future breeding program for antioxidant activity.

\section{CONCLUSION}

Among all the accession of $C$. aeruginosa, Sukoharjo (SH) and Muara Bungo (MB) showed promising accessions for antioxidant 
potential by free radical scavenging activity. Thus, these accessions important to selection for the future breeding program in pharmaceutical products.

\section{ACKNOWLEDGMENT}

We would like to thank Ministry of Research, Technology and Higher Education of the Republic of Indonesia for a research grant (547/IT3.11/PN/2016).

\section{REFERENCES}

Amalraj, A., Pius, A., Gopi, S., \& Gopi, S. (2017). Biological activities of curcuminoids, other biomolecules from turmeric and their derivatives-A review. Journal of Traditional and Complementary Medicine, 7, 205-233.

Bayr, H. (2005). Reactive oxygen species. Critical Care Medicine, 33(12), S498S501.

Bhattacharya, S. (2015). Reactive oxygen species and cellular defense system Free Radicals in Human Health and Disease (pp. 17-29): Springer.

Bi, W., He, C., Ma, Y., Shen, J., Zhang, L. H., Peng, Y., \& Xiao, P. (2016). Investigation of free amino acid, total phenolics, antioxidant activity and purine alkaloids to assess the health properties of non-Camellia tea. Acta Pharmaceutica Sinica B, 6(2), 170181.

Bos, R., Windono, T., Woerdenbag, H. J., Boersma, Y. L., Koulman, A., \& Kayser, O. (2007). HPLC-photodiode array detection analysis of curcuminoids in Curcuma species indigenous to Indonesia. Phytochemical Analysis, 18(2), 118122.

Carmona-Jiménez, Y., García-Moreno, M. V., Igartuburu, J. M., \& Barroso, C. G. (2014). Simplification of the DPPH assay for estimating the antioxidant activity of wine and wine by-products. Food Chemistry, 165, 198-204.

George, M., \& Britto, S. J. (2015). Phytochemicaland antioxidant studies on the essential oil of the rhizome of Curcuma aeruginosa Roxb. International Research Journal of Pharmacy, 6(8), 573-579.

Guo, W., Saito, S., Sanchez, C. G., Zhuang, Y., Rosero, R. E. G., Shan, B., . . .
Lasky, J. A. (2017). TGF- $\beta 1$ Stimulates HDAC4 Nucleus to Cytoplasm Translocation and NADPH Oxidase4-Derived Reactive Oxygen Species in Normal Human Lung Fibroblasts. American Journal of Physiology-Lung Cellular and Molecular Physiology, ajplung. 00256.02016.

Halliwell, B., \& Gutteridge, J. M. (2015). Free radicals in biology and medicine: Oxford University Press, USA.

Hecht, F., Pessoa, C. F., Gentile, L. B., Rosenthal, D., Carvalho, D. P., \& Fortunato, R. S. (2016). The role of oxidative stress on breast cancer development and therapy. Tumor Biology, 37(4), 4281-4291.

Jeong, S. C., Tulasi, R., \& Koyyalamudi, S. R. (2016). Antioxidant capacities of hot water extracts and endopolysaccharides of selected chinese medicinal fruits. Cancers, 8(3), 33.

Kilanczyk, E., Saraswat Ohri, S., Whittemore, S. R., \& Hetman, M. (2016). Antioxidant protection of NADPHdepleted oligodendrocyte precursor cells is dependent on supply of reduced glutathione. ASN Neuro, 8(4), 1759091416660404.

Li, J., Lin, J., Xiao, W., Gong, Y., Wang, M., Zhou, P., \& Liu, Z. (2013). Solvent extraction of antioxidants from steam exploded sugarcane bagasse and enzymatic convertibility of the solid fraction. Bioresource Technology, 130, 8-15.

Li, W. J., Cheng, X. L., Liu, J., Lin, R. C., Wang, G. L., Du, S. S., \& Liu, Z. L. (2012). Phenolic compounds and antioxidant activities of Liriope muscari. Molecules, 17(2), 1797-1808.

Nickavar, B., Alinaghi, A., \& Kamalinejad, M. (2008). Evaluation of the antioxidant properties of five Mentha species. Iranian Journal of Pharmaceutical Research, 7(3), 203-209.

Nurcholis, W., Khumaida, N., Syukur, M., \& Bintang, M. (2016a). Variability of curcuminoid content and lack of correlation with cytotoxicity in ethanolic extracts from 20 accessions of Curcuma aeruginosa RoxB. Asian 
Pacific Journal of Tropical Disease, 6(11), 887-891.

Nurcholis, W., Khumaida, N., Syukur, M., \& Bintang, M. (2016b). Variability of total phenolic and flavonoid content and antioxidant activity among 20 Curcuma aeruginosa Roxb. accessions of Indonesia. Asian Journal of Biochemistry, 11, 142-148.

Nurcholis, W., Khumaida, N., Syukur, M., Bintang, M., \& Ardyani, I. D. A. A. C. (2015). Phytochemical screening, antioxidant and cytotoxic activities in extracts of different rhizome parts from Curcuma aeruginosa Roxb. International Journal of Research in Ayurveda and Pharmacy, 6(5), 634637.

Onoue, T., Goto, M., Tominaga, T., Sugiyama, M., Tsunekawa, T., Hagiwara, D., . . . Arima, H. (2016). Reactive oxygen species mediate insulin signal transduction in mouse hypothalamus. Neuroscience Letters, 619, 1-7.

Park, G., Sim, Y., Lee, W., Sung, S. H., \& Oh, M. S. (2016). Protection on skin aging mediated by antiapoptosis effects of the water lily (Nymphaea Tetragona GEORGI) via reactive oxygen species scavenging in human epidermal keratinocytes. Pharmacology, 97(5-6), 282-293.

Perera, H. D. S. M., Samarasekera, J. K. R. R., Handunnetti, S. M., \& Weerasena, O. V. D. S. J. (2016). In vitro antiinflammatory and anti-oxidant activities of Sri Lankan medicinal plants. Industrial Crops and Products, 94, 610-620.

Pérez, J. A. M., \& Aguilar, T. A. F. (2013). Chemistry of Natural Antioxidants and Studies Performed with Different Plants Collected in Mexico. Oxidative stress and chronic degenerative diseases-a role for antioxidants, 59-85.

Phaniendra, A., Jestadi, D. B., \& Periyasamy, L. (2015). Free radicals: properties, sources, targets, and their implication in various diseases. Indian Journal of Clinical Biochemistry, 30(1), 11-26.

Radak, Z., Suzuki, K., Higuchi, M., Balogh, L., Boldogh, I., \& Koltai, E. (2016). Physical exercise, reactive oxygen species and neuroprotection. Free Radical Biology and Medicine, 98, 187-196.

Rajamma, A. G., Bai, V., \& Nambisan, B. (2012). Antioxidant and antibacterial activities of oleoresins isolated from nine Curcuma species. Phytopharmacology, 2(2), 312-317.

Rimessi, A., Previati, M., Nigro, F., Wieckowski, M. R., \& Pinton, P. (2016). Mitochondrial reactive oxygen species and inflammation: Molecular mechanisms, diseases and promising therapies. The International Journal of Biochemistry \& Cell Biology, 81, 281293.

Sverdlov, A. L., Elezaby, A., Qin, F., Behring, J. B., Luptak, I., Calamaras, T. D., . . . Shirihai, O. S. (2016). Mitochondrial reactive oxygen species mediate cardiac structural, functional, and mitochondrial consequences of dietinduced metabolic heart disease. Journal of the American Heart Association, 5(1), e002555.

Theanphong, O., Mingvanish, W., \& Kirdmanee, C. (2013). Chemical constituents and biological activities of essential oil from Curcuma aeruginosa RoxB. rhizome. Bulletin of Health, Science and Technology, 13(1), 6-16.

Tostes, R. C., Carneiro, F. S., Carvalho, M. H. C., \& Reckelhoff, J. F. (2016). Reactive oxygen species: players in the cardiovascular effects of testosterone. American Journal of Physiology-Regulatory, Integrative and Comparative Physiology, 310(1), R1-R14. 